\title{
Idioms in Colours
}

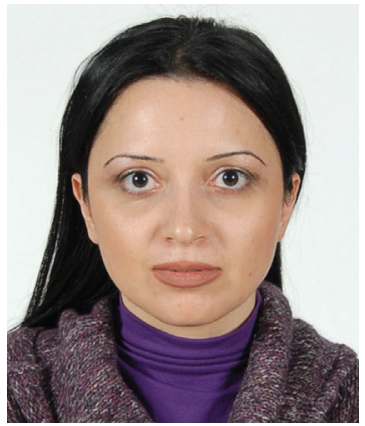

Kristine Harutyunyan
11 languages possess a great number of word-groups A which are known as idioms.

The use of idioms much depends on the context. Proceeding from the assumption that individual meanings of polysemantic words can be observed in a certain context it is argued that idioms are to be defined through specific types of context. Free word-groups make up variable contexts, whereas the essential feature of idioms is a non-variable or fixed context. Non-variability is understood as the stability of the word-group. In variable contexts which include polysemantic words, substitution of one of the components is possible within the limits of the lexical valency of the word under

consideration (Ginzburg 1979:72).

Idioms are to a great extent a product of culture. They come into being on the basis of the specific worldview of a particular speech community and reflect its empirical, historical and spiritual experience. As a manifestation of national wit as a particular sort of national creativity, idioms through the system of images, symbols and stereotypes fixed in them, carry on from generation to generation the accumulated culture and thus ensure national identity.

Idioms are claimed to have powerful cohesive force. Being institutionalized units of the language they are shared by all members of a given speech community or various subgroups within it and bind the members of such groups together as a manifestation of their identity. At the same time idioms have the power of keeping out non-members of the group and distinguishing such groups from others (New Developments in Modern Anglistics 1997:118). Taking into account all these peculiarities, idioms should be translated with special care.

Our research has shown that the idioms with colour terms that are found in the novels of British and American authors are translated in different ways into Armenian and Russian. The first variant of translation is to use the equivalent idiom existing in Armenian or Russian. On the other hand, if a corresponding equivalent is non-existent, idioms can be translated with the help of non-idiomatic expressions.

A certain number of examples are adduced below:

And round Crum were still gathered a forlorn hope of bluebloods with a plutocratic following.

(Galsworthy 104)

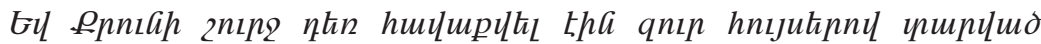

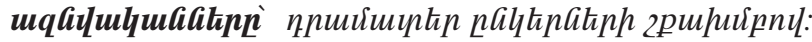

(Galsworthy 145) 
И вокруг Крума все еще собирались пердставители голубой крови с их былыми надеждами, а за ними тянулась плутократия.

(Galsworthy 438)

It always ends up making you blue as hell.

(Salinger 94)

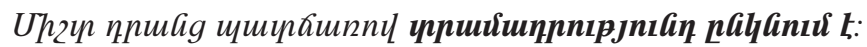

(Salinger 120)

Вечно из-за них расстраиваешься.

(Salinger 320)

In the first example the idiom blue blood has equivalents both in Armenian and Russian languages (though it is not introduced in the Armenian translation), whereas the idiom blue as hell is translated without the use of colour terms. The colour term blue has the meaning of sadness and gloominess only in the English language:

I've been thinking of the past and I am as blue as the devil.

(Maugham 62)

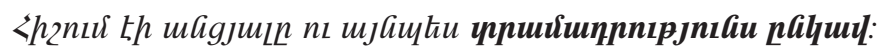

(Maugham 72)

Я думала о прошлом, и у меня теперь страшная хандра.

(Maugham 246)

I just felt blue as hell.

(Salinger 125)

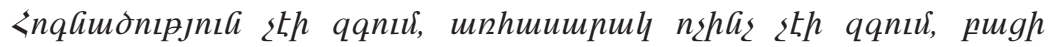
unuluilh чnnuninipjnitihg:

(Salinger 160)

Вообще ничего не чувствовал, кроме жуткой тоски.

(Salinger 349)

You are seeing blue tonight, old thing.

(Galsworthy 223)

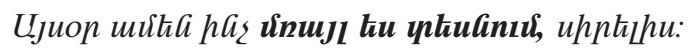

(Galsworthy 680) 
Сейчас тебе все представляется в мрачном свете.

(Galsworthy 455)

I have absolutely got to have an interest in life, or this country will give me the blues.

(Galsworthy 348)

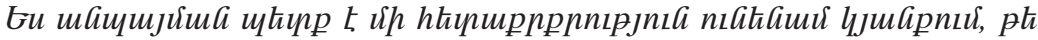

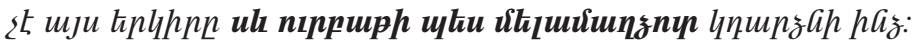

(Galsworthy 456)

Мне просто необходимо найти какой-то интерес в жизни, иначе эта страна нагонит на меня зеленую тоску.

(Galsworthy 651)

The last example seems to be more vivid and interesting as the idiom to give the blues is translated both into Armenian and Russian with the help of the idioms containing colour terms different from the original, i.e. black and green. Though the translators have used different colour terms, the translations are very appropriate as they reflect exactly the same mood that is expressed in the original. The fact that sadness in Armenian is of the black colour whereas in Russian it is green, can be explained by national and cultural peculiarities of the given languages.

One did not reach him or so it was reported by members of the family who, out of old-time habit or absent-mindedness, would drive up once in a blue moon and ask after their surviving uncle.

(Galsworthy 38)

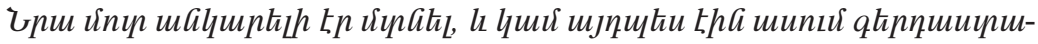

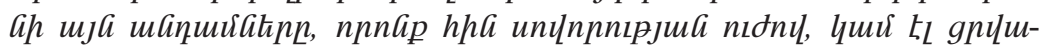

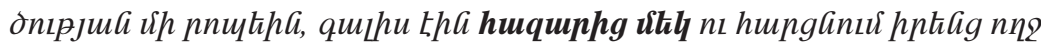

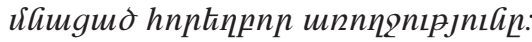

(Galsworthy 440)

До него не добраться, или так, по крайней мере утверждали те из родни, кто по старинной привычке или рассеянности нетнет, а заходили сюда проведать своего последнего дядю.

(Galsworthy 641)

Then all of a sudden, out of a clear blue sky, old Sally said, "Look, I have to know".

(Salinger 106) 


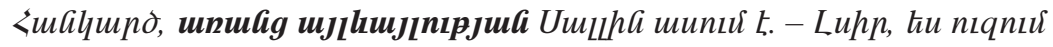

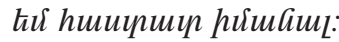

(Salinger 136)

Вдруг ни с того ни с сего, Салли спрашивает: - Слушай, мне надо точно знать.

(Salinger 331)

The idioms once in a blue moon and out of a clear blue sky have no equivalents in Armenian and Russian.

The majority of the idioms with the colour term white (uщhunul, белый) have positive meaning, whereas the idioms with the colour term black (ul, черный) are negative. Yet there are some exceptions: white elephant, to show the white feather in the black;

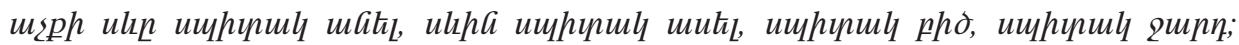
а́елая горячка, штопать белыми нитками, еtс.

His truly English pragmatism, could not help feeling that Michael would be well rid of a white elephant.

(Galsworthy 66)

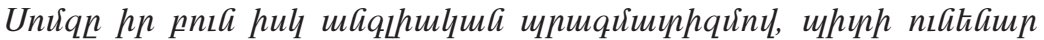

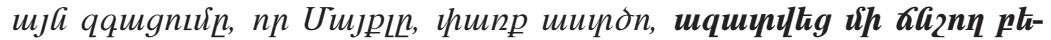
nhg:

(Galsworthy 455)

Сомс как истый англичанин, склонявшийся к прагматизму, констатировал бы с облегчением, что Майкл отделался от громоздкого бремени.

(Galsworthy 311)

The idiom white elephant is typical only of the English language.

Plenty of straight men racing but a lot of blackguards hanging about the sport.

(Galsworthy 92)

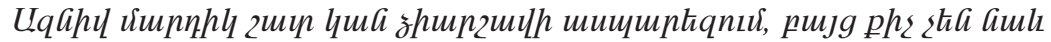

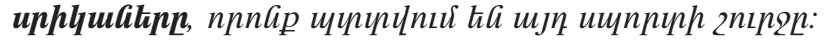

(Galsworthy147)

В мире скачек достаточно честных людей, но сколько мерзавцев примазывается со стороны!

(Galsworthy 568) 
Well, he would tackle it, write to Jon, and put the whole thing down in black and white.

(Galsworthy 176)

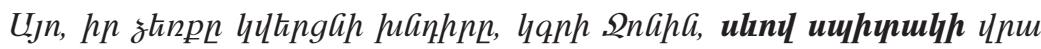

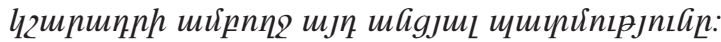

(Golsuordi 641)

Он напишет Джкону, изложит все как есть - черным по белому.

(Galsworthy 778)

- War-paint? -Yes, white waistcoat.

(Galsworthy 78)

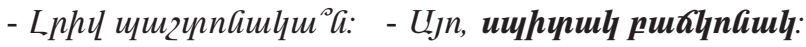

(Galsworthy 82)

- Полный парад? - Да, белый жслет.

(Galsworthy 58)

The idioms black and white and white waistcoat are translated with the help of the same colour terms. On the other hand the translation of blackguards is different.

This was early in December, so that when Black Week came, he was enabled to say to everybody...

(Galsworthy 130)

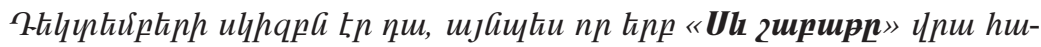

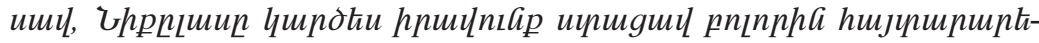
¿nt...

(Galsworthy 183)

Это было в самом начале декабря, так что, когда пришла “Черная неделя”, он мог всякому сказать..

(Galsworthy 465)

Black week is 10-15 December, 1899. During this short period the English army suffered a number of defeats. This expression can be understood correctly in case of one's good knowledge of the history of Britain (cf. Black Tuesday).

Coming hastily out of a door, he received simultaneously a black eye.

(Galsworthy 


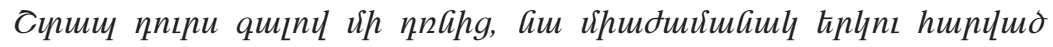

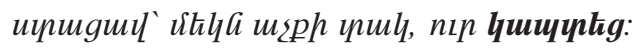

(Galsworthy 503)

Поспешно войдя в умывальную, он тотчас же получил синяк под глазом.

(Galsworthy 343)

In this example again the colour term black is replaced by another one.

And he would live to a green old age, like his dear father.

(Galsworthy 242)

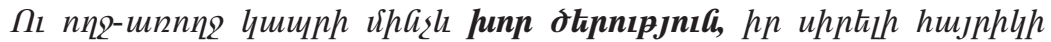
aиiua:

(Galsworthy 344)

И он доживет до глубокой старости, как его дорогой отец.

(Galsworthy 577)

"Well", he said," they brought me up to do nothing, and here I am in the sear and yellow, getting poorer every day".

(Galsworthy 14)

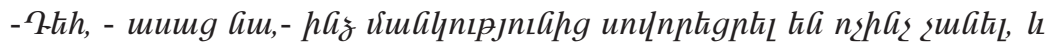

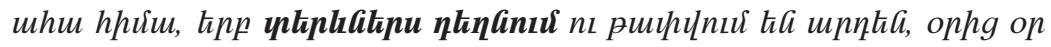

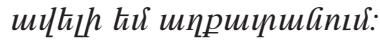

(Galsworthy 406)

-Да,- сказал он,- я так воспитан, чтобы ничего не делать, и вот теперь, на склоне лет моих, нищаю с каждым днем.

(Galsworthy 618)

The colour terms green and yellow refer to an old age only in English. However, in

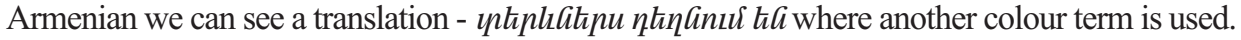

I am one of these very yellow guys.

(Salinger 75)

su h pak yuhulnyn tur:

(Salinger 95)

Я по природе трус.

(Salinger 302) 
It is funny kind of yellowness, wthen you come to think of it, but it is yellowness, all right.

(Salinger 76)

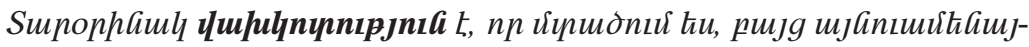
ahy, yuhlynynipjnia 5 :

(Salinger 97)

Странная трусость, если подумать, но все жее это трусость.

(Salinger 303)

The colour term yellow in English is connected with cowardice and sensation. The

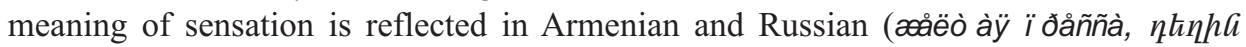
ปuर्nL), but yellow in the meaning of cowardice is peculiar only to English.

People live in the world full of colours which acquire different symbolic meanings. The meaning of the idioms containing colour terms is connected with the symbolic associations that exist in the particular speech community. This fact can't be neglected in the process of translation.

Idiomatic paremiological dictionaries are full of amusing periphrases of wellknown idioms, proverbs and sayings, which, in fact, have very little to do with the complex meaning of the corresponding unit. It is not surprising therefore that these rather impressionistic definitions are of no or very little help to the user of language who is unable to form the necessary link between the meaning of an idiom and an appropriate discourse situation. Especially it affects foreign learners who fail to make a proper choice to match a particular speech event (New Developments in Modern Anglistics 1997:110).

\section{References:}

1. Ginzburg, R. et al. (1979) A Course in Modern English Lexicology. M.: Vyshaya shkola.

2. New Developments in Modern Anglistics (1997) M.: Moscow University Press.

\section{Sources of Data:}

1. Galsworthy, J. A. (1975) The Forsyte Saga. Books 1, 2. M.: Progress Publishers.

2. Galsworthy, J. A. (1975) Modern Comedy. Books 1, 2. M.: Progress Publishers.

3. Galsworthy, J. A. (1973) Saga o Forsaytakh. Tr. by N. Voljina, M. Bogoslavskaya, N. Bobrova, Vol. 1, 2, 3. M.: Khudozhestvennaya literatura.

4. Galsworthy, J. A. (1973) Sovremennaya komedia. Tr. by R. Rayt-Kovaleva, A. Krivcova, M. Lorie. Vol. 1, 2, 3. M.: Khudozhestvennaya literatura. 
5. Galsworthy, J. A. (1977) Forsaytneri patmutyun. Tr. by K. Surenyan. Vol. 1, 2, 3. Yerevan: Sovetakan grogh.

6. Galsworthy, J. A. (1980) Jamanakakic katakergutyun. Tr. by K. Surenyan. Vol. 1, 2, 3. Yerevan: Sovetakan grogh.

7. Maugham, W. S. (1985) Theatre. M.: Vyshaya Shkola.

8. Maugham, W. S. (1983) Teatr. Tr. by G. Ostrovskaya. M.: Pravda.

9. Maugham, W. S. (1985) Tatron. Tr. by J. Hovhannisyan. Yerevan: Sovetakan grogh.

10. Salinger, J. D. (1982) Catcher in the Rye. New-York: A National General Company.

11. Salinger, J. D. (1982) Nine Stories. M.: Progress Publishers.

12. Salinger, J. D. (1982) Raise the Roof Beam, Carpenters. M.: Progress Publishers.

13. Salinger, J. D. (1999) Nad propostyu vo rji. Tr. by R. Rayt-Kovaleva. Kharkov: Folio.

14. Salinger, J. D. (1999) Devyat rasskazov. Tr. by R. Rayt-Kovaleva. Kharkov: Folio.

15. Salinger, J. D. (1999) Vyshe stropila, plotniki. Tr. by R. Rayt-Kovaleva. Kharkov: Folio.

16. Salinger, J. D. (1978) Tarekani artum andundi ezrin. Tr. by A. Ghukasyan. Yerevan: Sovetakan grogh.

17. Salinger, J. D. (1978) Tspeghneri bardzr ataghdzagortsner. Tr. by A. Ghukasyan. Yerevan: Sovetakan grogh.

18. Salinger, J. D. (1978) (1978) Iny patmvatsq. Tr. by A. Ghukasyan. Yerevan: Sovetakan grogh.

\section{9-nıfiujhfi nupăıludpgitip}

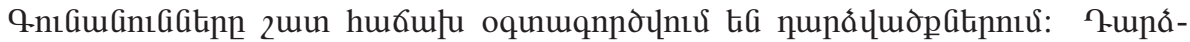

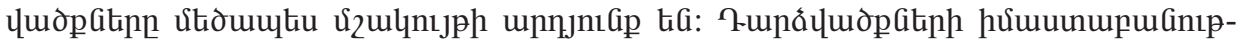

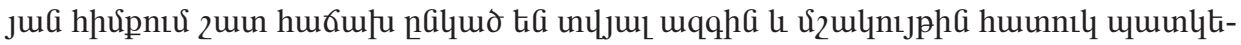

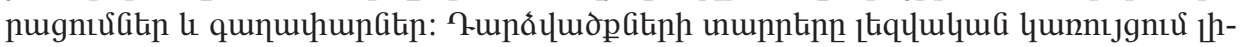

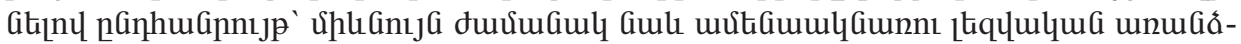

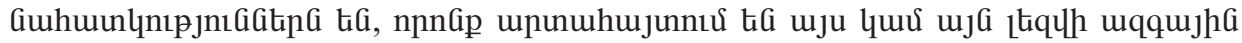

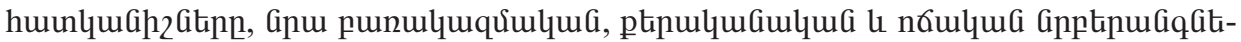
nए:

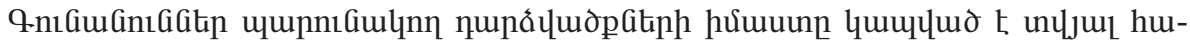

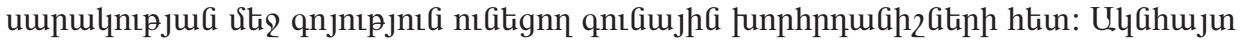

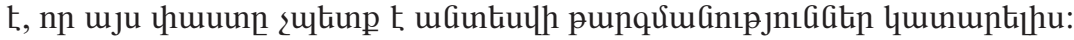

